\title{
The Effectiveness of Stone Column Spacing in Reducing The Potential of Liquefaction
}

\author{
Maulana Arif ${ }^{a^{*}}$, Meilani Adriyati ${ }^{\mathrm{b}}$ \\ ${ }^{a}$ Program Studi Teknik Sipil Universitas Muhammadiyah Bangka Belitung, Jl. KH. Ahmad Dahlan km 4, Bangka Tengah, 33684, Indonesia \\ ${ }^{\mathrm{b}}$ Department of Civil and Structural Engineering Kyushu University, Fukuoka 819-0395, Japan
}

Kata kunci:

Likuefaksi

Stone Column

Quake/W

\begin{abstract}
ABSTRAK
Likuefaksi merupakan fenomena pencairan tanah akibat adanya beban siklik atau gempa. Salah satu metode penanganan likuefaksi yaitu dengan melakukan instalasi stone column. Stone column merupakan suatu kolom yang diisi oleh fragmen batuan yang dipadatkan. Umumya kolom berukuran diameter $50 \mathrm{~cm}$ dan kedalaman hingga $5 \mathrm{~m}$. Metode ini dipercaya dapat mengurangi tekanan air pori yang terjadi pada tanah saat gempa. Penelitian ini bertujuan untuk mengetahui efektifitas stone collumn dalam mengurangi potensi likuefaksi. Penelitian ini dilakukan dengan menggunakan data bor dan uji laboratorium. Simulasi numeris juga dilakukan berupa permodelan tanah dengan stabilisasi stone column. Variasi pada jarak stone solumn $(2 \mathrm{~m} ; 1,5 \mathrm{~m}$; dan $1 \mathrm{~m})$ dan titik tinjau $(1 \mathrm{~m} ; 1,5 \mathrm{~m} ; 2 \mathrm{~m}$; dan $2,5 \mathrm{~m})$ dilakukan dengan menggunakan perangkat lunak Quake/w dari Geostudio 2012. Hasil menunjukkan bahwa potensi likuefaksi dapat berkurang dengan jarak stone column yang semakin dekat hingga $1,5 \mathrm{~m}$. Pengurangan tekanan air pori dan potensi likuefaksi hanya terjadi pada periode awal gempa sebelum mencapai puncak percepatan gempa.
\end{abstract}

\begin{abstract}
Liquefaction is a liquefied soil phenomenon caused by cyclic load or earthquake. One of the soil liquefaction prevention methods is the installation of stone column. The stone column is a column filled with compacted rock fragments. It has $50 \mathrm{~cm}$ in diameter and $5 \mathrm{~m}$ deep This method is believed to reduce the excess pore water pressure that occurs during an earthquake. The stone column has been applied in many construction projects which located in high potential of liquefaction area. This research aims to know the effectiveness of stone column in reducing the liquefaction potential. This research conducted by using borelog data and soil laboratory test. This research also runs the numerical simulation of soil liquefaction with stone column stabilization. The variations in column spacing $(2 \mathrm{~m} ; 1.5 \mathrm{~m}$; and $1 \mathrm{~m})$ and subsurface review point $(1 \mathrm{~m} ; 1.5 \mathrm{~m} ; 2 \mathrm{~m}$; and $2.5 \mathrm{~m})$ will be applied by using Quake/W from Geostudio 2012 software. The results show that the liquefaction potential can be reduced with the closer stone column spacing up to $1.5 \mathrm{~m}$. Reduction of pore water pressure and liquefaction potential only occurs in the initial period of the earthquake before reaching the peak of earthquake acceleration.
\end{abstract}

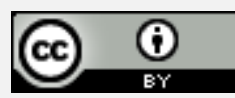

This is an open access article under the CC-BY license.

\section{Introduction}

Indonesia is one of the countries located passed by the ring of fire and the boundaries of the 4 major plates of the world (Indo Australian Plate, Eurasian Plate, Pacific Plate, and Philippine Plate. This condition makes Indonesia one of the countries with high seismic potential. Earthquake events are commonplace and often occur in Indonesia. Many impacts were caused by this earthquake, one of which is the phenomenon of liquefaction.

Liquefaction can simply be interpreted as melting soil. Meanwhile, the understanding of liquefaction specifically is a saturated sandy soil phenomenon that experiences a large cyclic load in the form of 
earthquakes with a certain time increasing pore water pressure which decreases the effective stress on the soil so that the soil loses its bearing capacity [1]. It can be expressed from Eq.1 where $\sigma^{\prime}$ is the soil effective stress $\left(\mathrm{kN} / \mathrm{m}^{2}\right), \sigma$ is the soil total stress $\left(\mathrm{kN} / \mathrm{m}^{2}\right)$ and $u$ is the pore water pressure $\left(\mathrm{kN} / \mathrm{m}^{2}\right)$

$$
\sigma^{\prime}=\sigma-u
$$

The 2018 Palu liquefaction event reminds us that the potential for liquefaction disasters in Indonesia is quite high and requires special attention. In 2019
Badan Geologi Pusat Air Tanah dan Geologi Tata Lingkungan released a map of the potential for liquefaction throughout Indonesia [2]. It can be seen in Figure 1 that the liquefaction potential occurs in coastal areas that are close to the seismic zone. Purple color indicates a zone of high liquefaction potential, yellow color indicates a zone of moderate liquefaction potential, green color indicates a zone of low liquefaction potential, and gray indicates a zone with no potential for liquefaction.

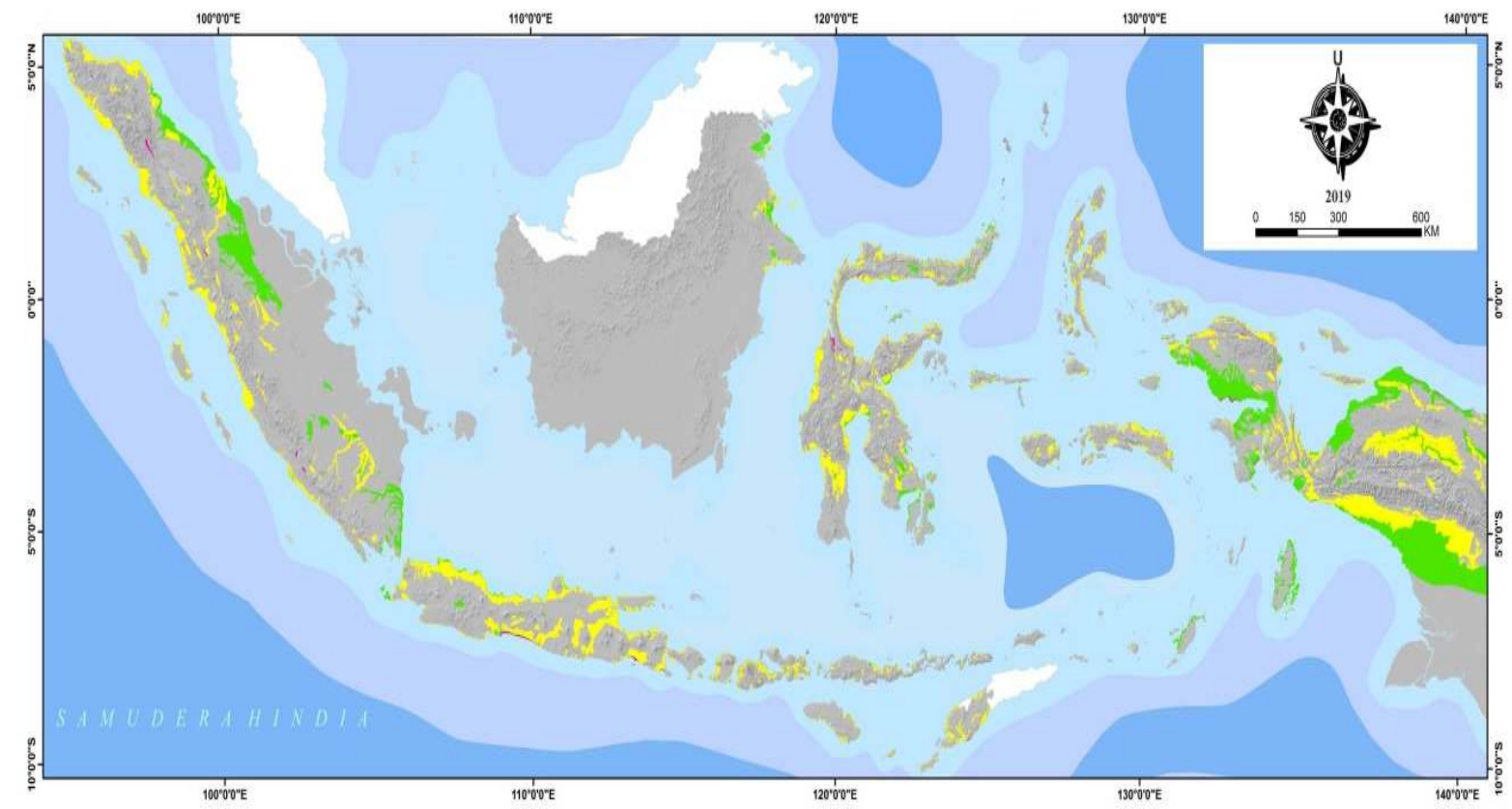

Figure 1. The Liquefaction Potential Map of Indonesia

According to the [3], when liquefaction occurs it can trigger several failures such as sand boils, flow failures, lateral spreads, ground oscillation, loss of carrying capacity, buildings drop into the ground, and so on. One method that can be used in soil improvement to prevent liquefaction is the stone column method. The principle of the stone column itself is to dispense excess pore water pressure as quickly as possible so that the excess pore water pressure that occurs due to the cyclic load caused by the earthquake does not exceed the effective stress of the soil. [1] states that stone columns are very suitable for increasing soil bearing capacity, slope stability, reducing subsidence, accelerating consolidation, and reducing the liquefaction potential. This soil improvement technique using stone columns is excellent for use in structures that have large areas such as embankments.

From Figure 2, [4] said that the stone column installation process involves the use of a rotating digging and vibrating device. Installation of a stone column begins with drilling in the soil and then the coarse material (gravel) is inserted and compacted into the drill hole. Especially for soils that contain a lot of fine material such as silt, wick drains or PVD (Prefabricated Vertical Drain) are installed between the stone columns which help water out of the ground (Figure. 1). 

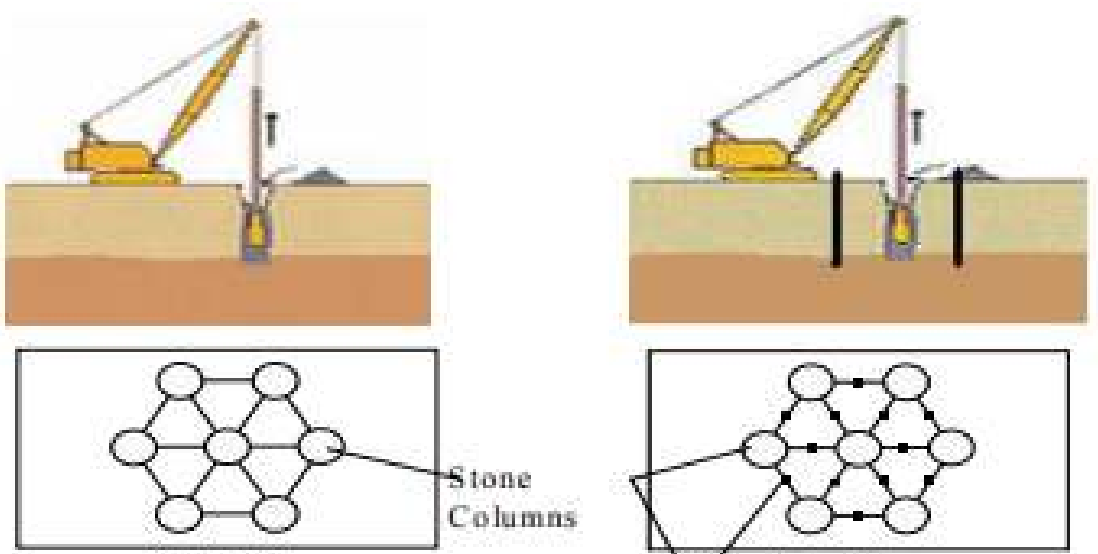

Plan View
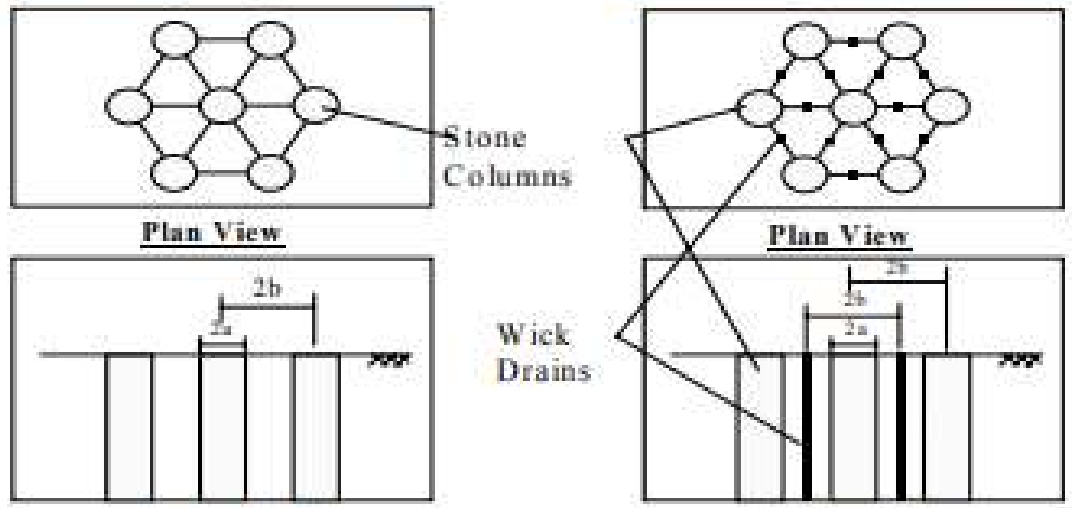

Elevation

Elevation

Figure 2. Stone column installation

[5] used numerical methods in determining the effectiveness of stone columns in preventing an increase in pore water pressure during an earthquake. By doing axisymmetric modeling, they divided the zones of the model as granular column, disturbed zone, and undisturbed zone.

Based on the results of modeling by [5] in Figure 3, the spacing of stone columns which is represented by the ratio of disturbed zone and granular column $(s / c)$, affected the ratio of maximum pore pressure $\left(r_{u}{ }^{\max }\right)$. In this case, the $s / c$ value is varied from 1 to 3 . The smaller the $s / c$ value used, the smaller the peak value of the $r_{u}{ }^{\max }$ will be. This indicates that the spacing of the stone columns greatly affects their effectiveness in reducing the increase in pore water pressure. The closer of stone column spacing, the smaller of maximum pore pressure occurs.

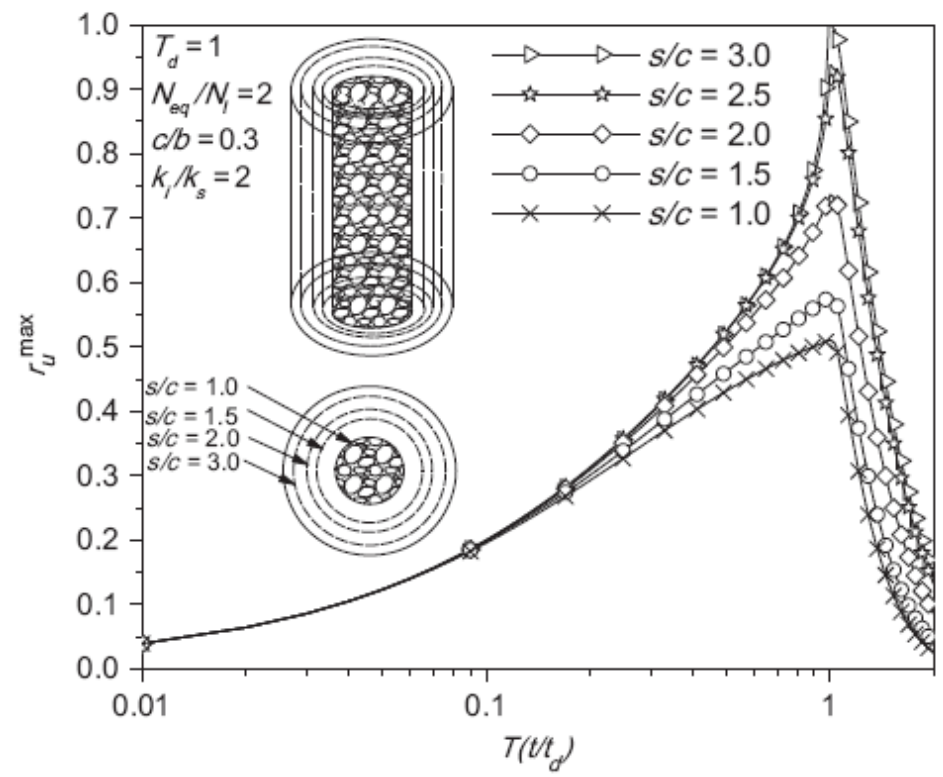


Figure 3. Variation of maximum pore pressure ratio $\left(r_{u}{ }^{\max }\right)$ to time function $(T)$ for different $s / c$

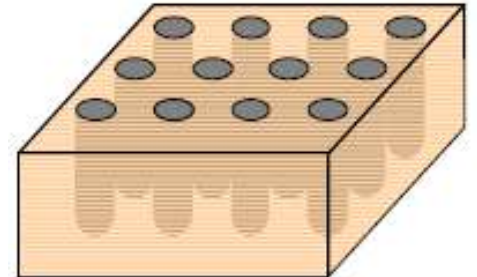

(a)

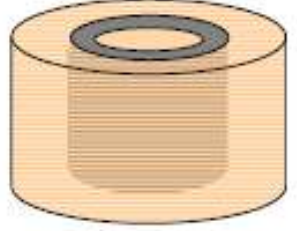

(d)

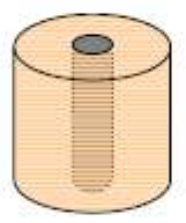

(b)

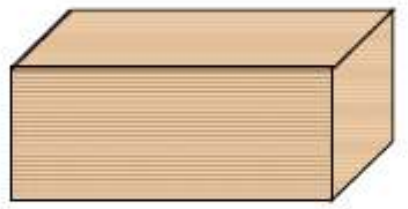

(e)

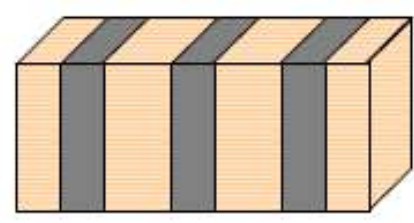

(c)

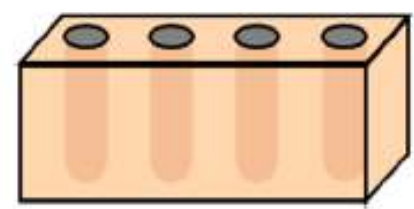

(f)

Figure 4. Stone column geometric model : (a) 3D model; (b) Unit cell; (c) Longitudinal gravel trenches; (d) Cylindrical gravel rings; (e) Equivalent homogenous soil; (f) 3D slice of columns.

One of the most important aspects related to modeling is geometry. The geometry of the stone column modeling is simplified into several geometric model shapes that are adapted to the original conditions in the field. Figure 4 shows a commonly used geometric model. Besides geometry, another important parameter in modeling is the input property data used in the model. This property data input is very important and must be close to the original conditions in the field. Input parameters include the stone column material and the surrounding soil.

Table 1 shows that the modulus of elasticity $\left(E_{c}\right)$ generally ranges from $25-35 \mathrm{MPa}$. The value of the internal friction angle $\left(\varphi_{c}\right)$ is in the range of 35-42. The volume weight value is in the range of 15-20 $\mathrm{kN} / \mathrm{m}^{3}$ for dry condition and $15-23.5 \mathrm{kN} / \mathrm{m}^{3}$ for wet condition, and the poisson ratio value is generally 0.2-0.3.

Table 1. Some input parameter values for stone column [6]

\begin{tabular}{cccccccc}
\hline Reference & $\boldsymbol{\varphi}_{\mathbf{c}}\left(^{\circ}\right)$ & $\boldsymbol{\Psi}_{\mathbf{c}}\left(^{\circ}\right)$ & $\mathbf{E}_{\mathbf{c}}(\mathbf{M P a})$ & $\mathbf{v}$ & $\mathbf{m}$ & $\boldsymbol{\gamma}_{\mathbf{d}}\left(\mathbf{k N} / \mathbf{m}^{\mathbf{3}}\right)$ & $\boldsymbol{\gamma}_{\mathbf{s a t}}\left(\mathbf{k N} / \mathbf{m}^{\mathbf{3}}\right)$ \\
\hline Ng \& Tan (2015) & 40 & 0 & 30 & 0.3 & - & - & 15 \\
Castro et al. (2014) & 42 & 12 & 35 & 0.2 & - & 16 & 19 \\
Adam et al. (2010) & 35 & 5 & 25 & 0.2 & 0.3 & 20 & 23.5 \\
Elshazhy et al. (2008) & 41 & - & 29.2 & 0.2 & 0.59 & 18.6 & 21.6 \\
Tan \& Tjahyono (2008) & 40 & - & 30 & 0.3 & - & 15 & 15 \\
\hline
\end{tabular}

\section{Research Method}

The research was conducted using primary data of SPT bore $\operatorname{logs}$ and laboratory test results. The parameters obtained from the data are used as input parameters in modeling using the Geostudio 2012-Quake / W software.

\subsection{Soil Condition}

Based on the data obtained, the soil layer that prone to be liquefied is the sand layer with a thickness of $6.5 \mathrm{~m}$. The liquefaction safety factor of sand layer was range 
between 0.11-1.06 [7]. Sand layer was classified as loose sand and medium dense sand. Below the sand layer also exist stiff clay layer until the depth of $20 \mathrm{~m}$. The groundwater table observed at $0.9 \mathrm{~m}$. Table 2 shows the description of each liquefiable sand layer.

\subsection{Geostudio 2012-Quake/W Modeling}

Liquefaction numerical modeling is carried out in two dimensions using Geostudio 2012 software. Geostudio 2012 software has several different analysis programs. In this study, the Quake / W program was used as a modeling tool for determining the potential of liquefaction

The input of soil parameter values in modeling using Geostudio 2012 software consists of soil density $(\gamma)$, maximum shear modulus $\left(G_{\max }\right)$, and Poisson's ratio $(v)$, assuming a linear elastic model, see Table 3. The maximum soil shear modulus $\left(G_{\max }\right)$ was determined using Eq. 2 proposed by [8]. Meanwhile, the determination of Poisson's ratio $(v)$ is determined based on the equation proposed by [9] for loose sand (Eq. 3), dense sand (Eq. 4), and stiff clay (Eq. 5)

$G_{\max }=16.03 N^{0,65}$

$v=0.2+0.01 N$ $v=0.2+0.005 N$

$v=0.125+0.0125 \mathrm{~N}$

The model which determine the liquefaction potential was carried out through two conditions, the soil condition without the stone column installation and the soil condition with the stone column installation. The pore water pressure and the effective stress of soil are the two conditions that will be compared to see how big the liquefaction potential is.

In modeling the conditions during an earthquake, the analysis carried out is slightly different from the input earthquake parameters. Earthquake data used is in the form of time history curve data, the relationship between acceleration and time, which is adjusted to the research location around the subduction zone of the island of Java. Figure 5 shows the time history data that adjusted to the conditions of the 2006 Yogyakarta earthquake with an earthquake period of 80 seconds and the maximum peak ground acceleration value of $0.45 \mathrm{~g}$ according to the calculation results based on SNI 2017 [10].

Table 2. Sand layer characteristics

\begin{tabular}{llll}
\hline \multicolumn{1}{c}{ Soil type } & Depth $(\mathrm{m})$ & SPT value & \multicolumn{1}{c}{ Description } \\
\hline Loose sand & $0-5$ & $2-10$ & $\begin{array}{l}\text { Fine to medium sand, dark } \\
\text { brown, loose, poorly graded }\end{array}$ \\
\hline Medium dense sand & $5-6.5$ & 31 & $\begin{array}{l}\text { Fine to medium sand, dark } \\
\text { brown, dense, poorly graded }\end{array}$ \\
\hline Stiff clay & $6.5-20$ & $13-30$ & $\begin{array}{l}\text { Clay, dark brown to greyish } \\
\text { brown, stiff, medium to high } \\
\text { plasticity }\end{array}$ \\
\hline
\end{tabular}

Table 3. The Input Parameter of Model

\begin{tabular}{llll}
\hline Materials type & $\gamma\left(\mathrm{kN} / \mathrm{m}^{3}\right)$ & $G_{\max * *}(\mathrm{Mpa})$ & $v^{* * *}$ \\
\hline Loose sand & 17.16 & 39.47 & 0.24 \\
\hline Medium dense sand & 18.63 & 114.17 & 0.3 \\
\hline Stiff clay & 18.2 & 101.1 & 0.3 \\
\hline Stone Column & $19^{*}$ & 193 & $0.2^{*}$ \\
\hline$*[11]^{* *}[8]^{* *}[9]$ & & &
\end{tabular}




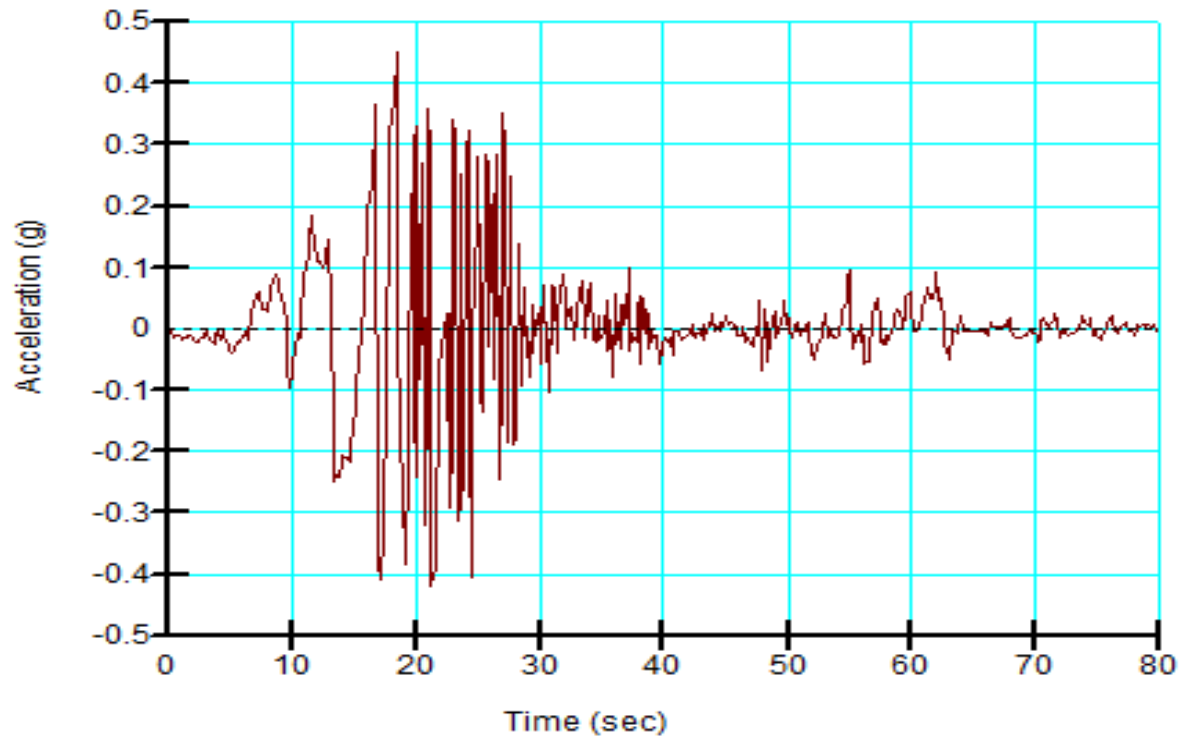

Figure 5. Time history curve used in dynamic analysis

From Figure 6, the left and right boundaries of the model in dynamic analysis are the boundary conditions where the vertical direction is locked (fixed $y$ ) with the assumption that when an earthquake occurs, the dominant ground conditions move in the horizontal direction. For the lower boundary, the boundary condition assumes that the horizontal and vertical directions are locked or fixed $x / y$.
The stages of soil modeling with stone column for dynamic conditions are relatively same as dynamic modeling for soils without stone column. The only difference lies in the addition of stone column model material. In this modeling, the stone columns spacing is varied by $2 \mathrm{~m}, 1.5 \mathrm{~m}$, and $1 \mathrm{~m}$. Then the pore water pressure and effective stress will be reviewed at $1 \mathrm{~m}, 1.5$ $\mathrm{m}, 2 \mathrm{~m}$, and $2.5 \mathrm{~m}$ depth.
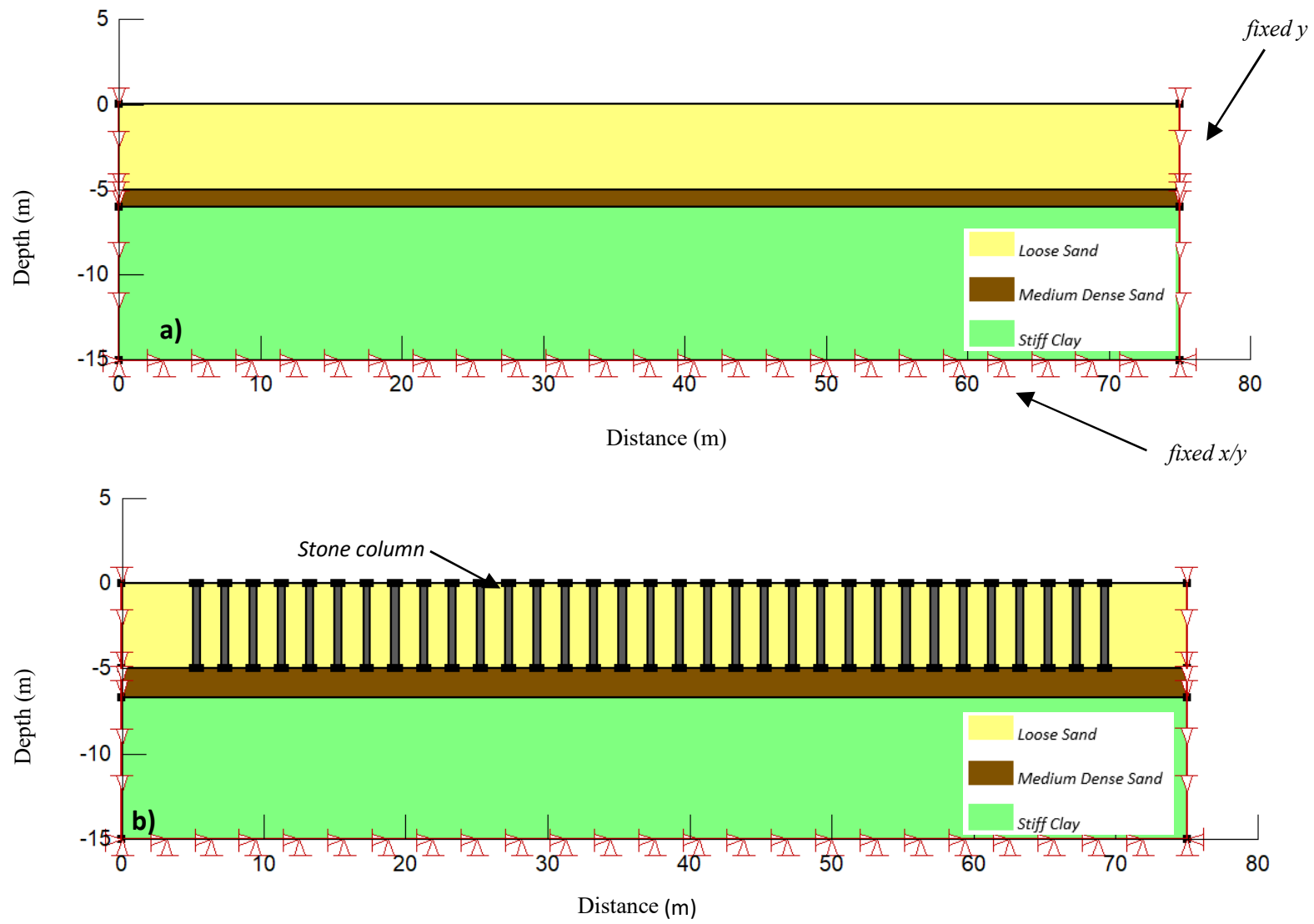

Figure 6. The soil modeling by using Geostudio 2012-Quake/W a) initial condition, b) stone column installation 


\section{Result and Discussion}

Based on the analysis of dynamic conditions, there was an increase in groundwater level due to the earthquake. The groundwater level was initially at a depth of $0.9 \mathrm{~m}$. After the earthquake, the groundwater level rose closer to the ground level. The increase in groundwater level occurs due to excess pore water pressure in the soil.

Figure 7 shows the curve of the increase in pore water pressure for soil with varied stone column spacing and without the stone column. It can be seen that with the addition of stone columns that were varied at the spacing of $2 \mathrm{~m}, 1.5 \mathrm{~m}$, and $1 \mathrm{~m}$. The additional of the stone column was only affected at review point depth of $1 \mathrm{~m}$ and $1.5 \mathrm{~m}$. Meanwhile, at the depth of $2 \mathrm{~m}$ and $2.5 \mathrm{~m}$, there was no significant change. Then the effectiveness of varied spacing of stone column was only in spacing of $2 \mathrm{~m}$ and $1.5 \mathrm{~m}$, beside the $1 \mathrm{~m}$ of spacing give the same result as spacing of $1.5 \mathrm{~m}$.

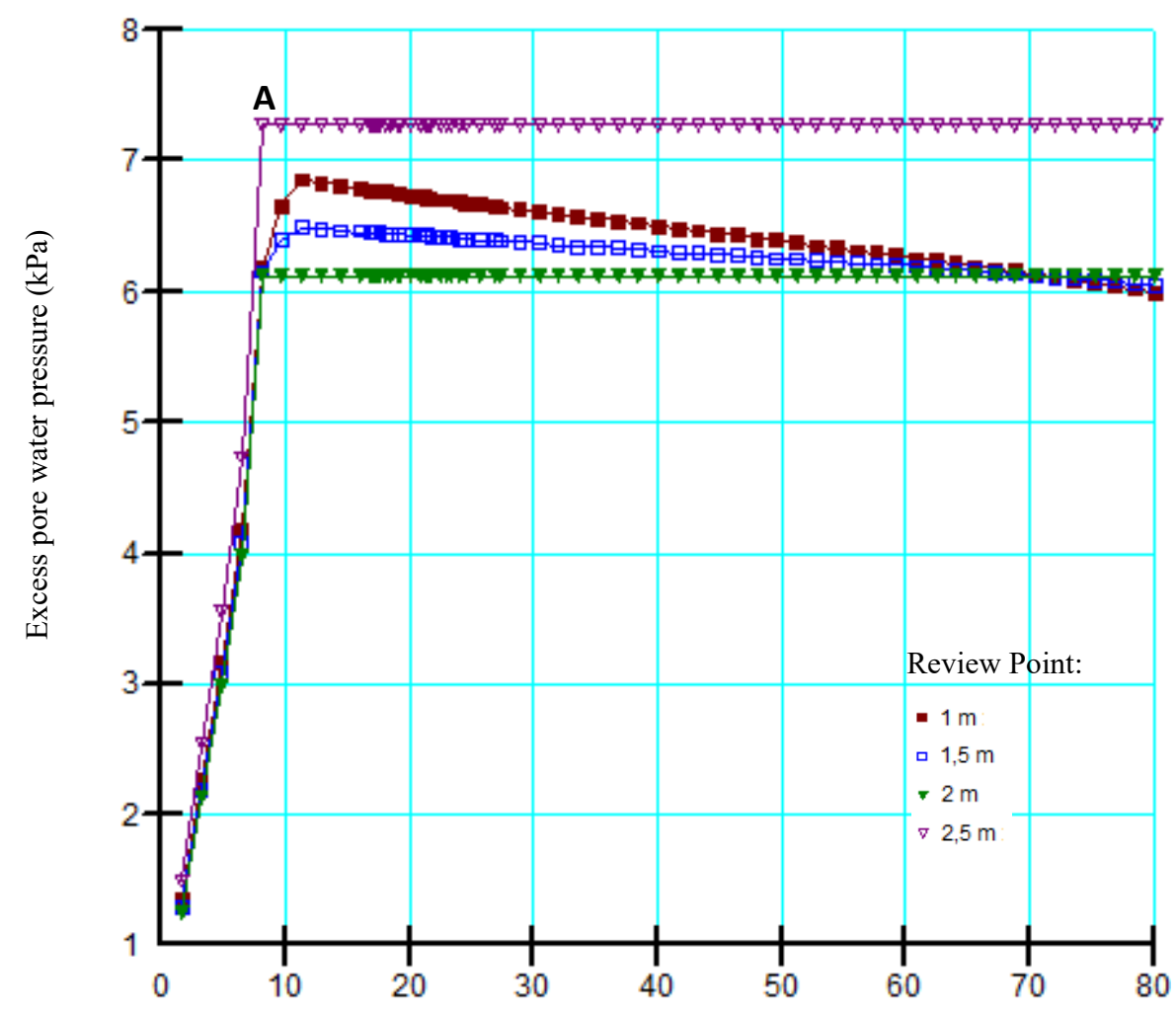



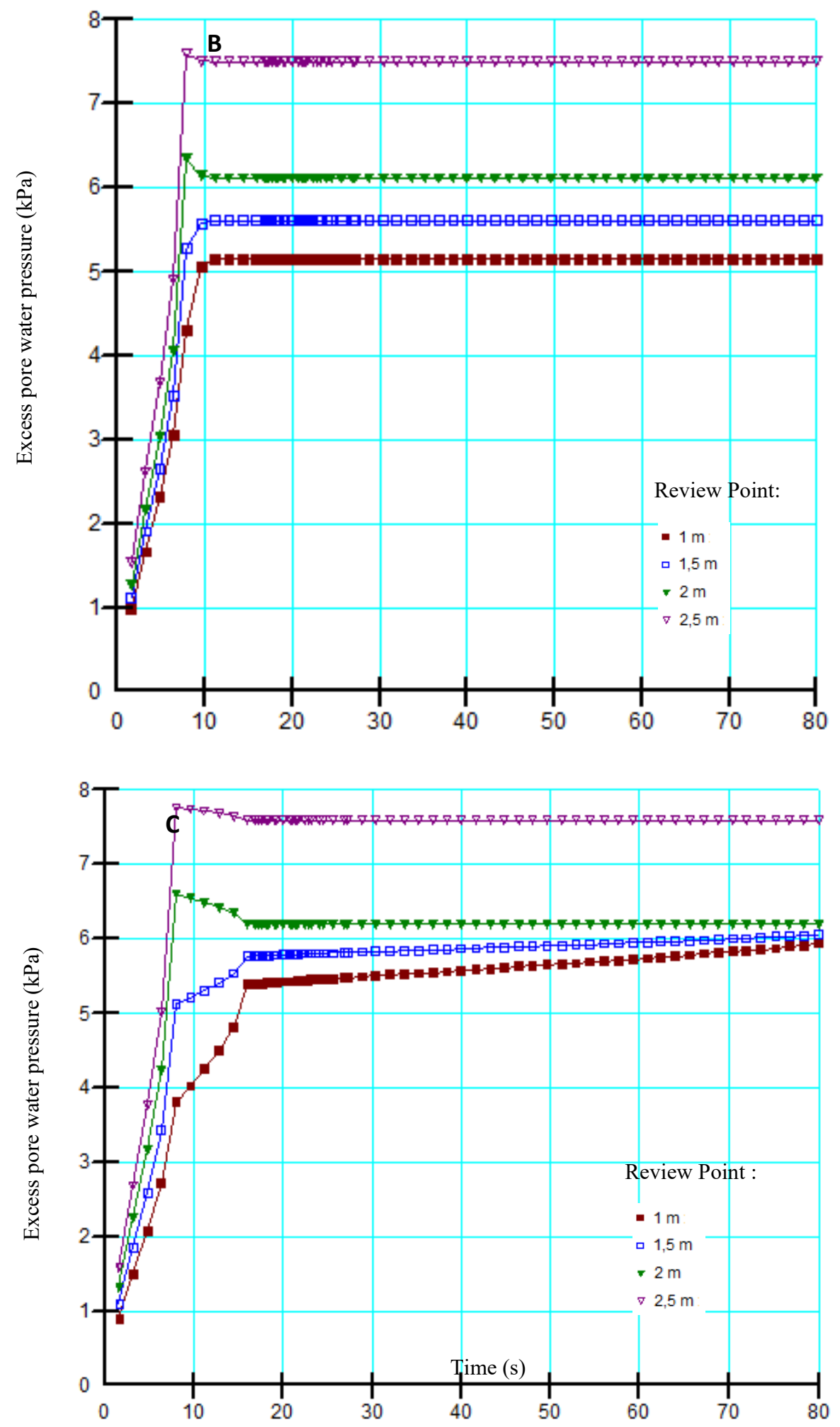


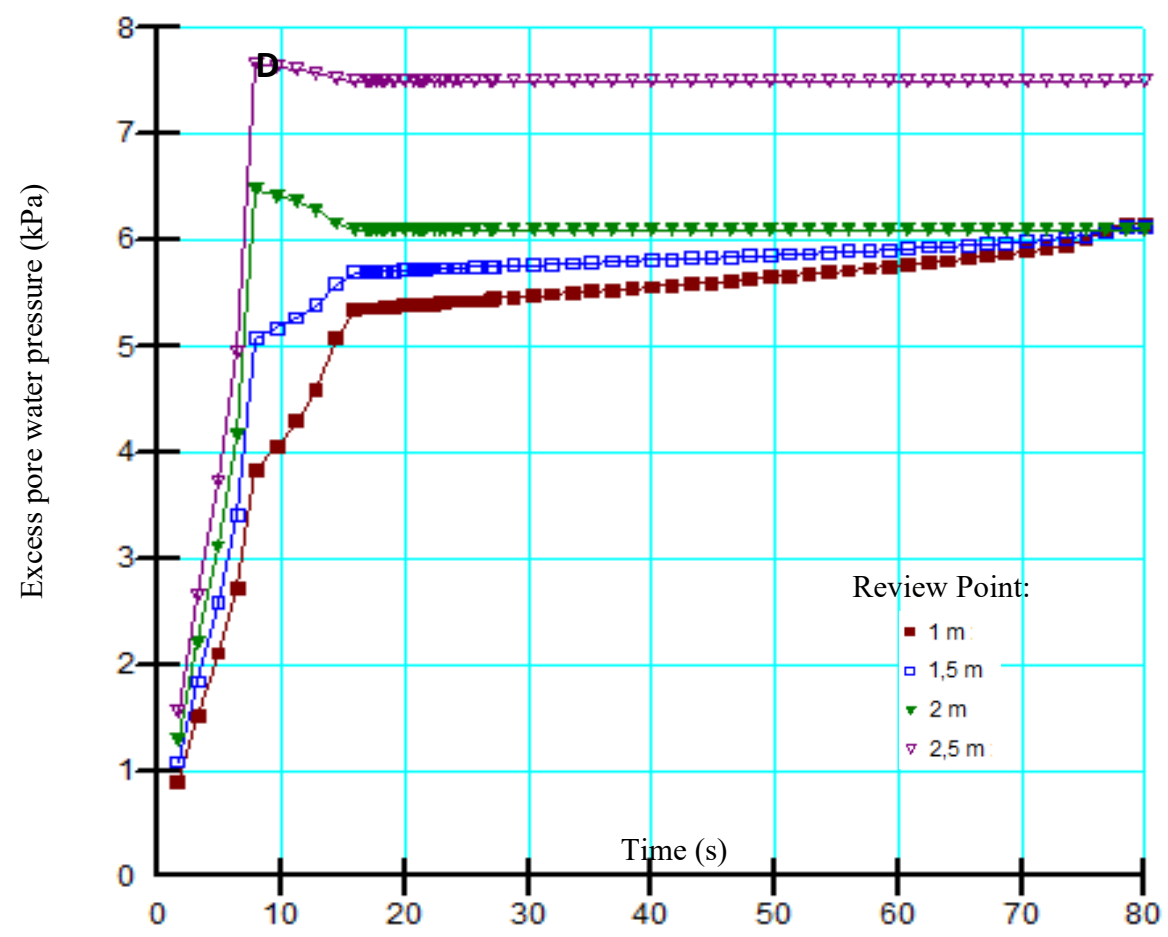

Figure 7. Curve of excess pore water pressure a) without stone column, b) stone column spacing $2 \mathrm{~m}$, c) stone column spacing $1.5 \mathrm{~m} \mathrm{~d}$ ) stone column spacing $1 \mathrm{~m}$

At the $1 \mathrm{~m}$ depth review point, initially, the peak of the increase in excess pore water pressure occurred at the 11th second of $6.9 \mathrm{kPa}$ (red line in Figure 6a), then the addition of stone column with $2 \mathrm{~m}$ in spacing, the increasing of pore water pressure can be reduced from $6.9 \mathrm{kPa}$ to $5.1 \mathrm{kPa}$ (red line in Figure 6b). There was a $26 \%$ reduction of excess pore water pressure caused by the addition of stone columns. Furthermore, the addition of stone column with $1.5 \mathrm{~m}$ in spacing, the increasing of excess pore water pressure can be reduced from $6.9 \mathrm{kPa}$ to $4.2 \mathrm{kPa}$ (red line in Figure 6c). There was a $40 \%$ reduction of excess pore water pressure caused by the addition of stone columns.

At the $1.5 \mathrm{~m}$ depth review point, initially, the peak of the increase in pore water pressure also occurs at the 11th second of $6.5 \mathrm{kPa}$ (blue line in Figure 6a), then the increase in pore water pressure can be reduced from 6.5 $\mathrm{kPa}$ to $5.6 \mathrm{kPa}$ (blue line in Figure $6 \mathrm{~b}$ ) after the stone column addition with $2 \mathrm{~m}$ in spacing. There was a $14 \%$ reduction in excess pore water pressure. Then the addition of stone column with $1.5 \mathrm{~m}$ in spacing, the increasing of excess pore water pressure can be reduced from $6.5 \mathrm{kPa}$ to $5.2 \mathrm{kPa}$ (red line in Figure 6c). There was a $20 \%$ reduction of excess pore water pressure.

The liquefaction potential can be seen by applying the ratio value between pore pressure and total stress based on Eq.1. If the ratio value between pore water pressure and total stress $(\mathrm{u} / \sigma)$ is closer to 1 , then the liquefaction potential will be higher. 


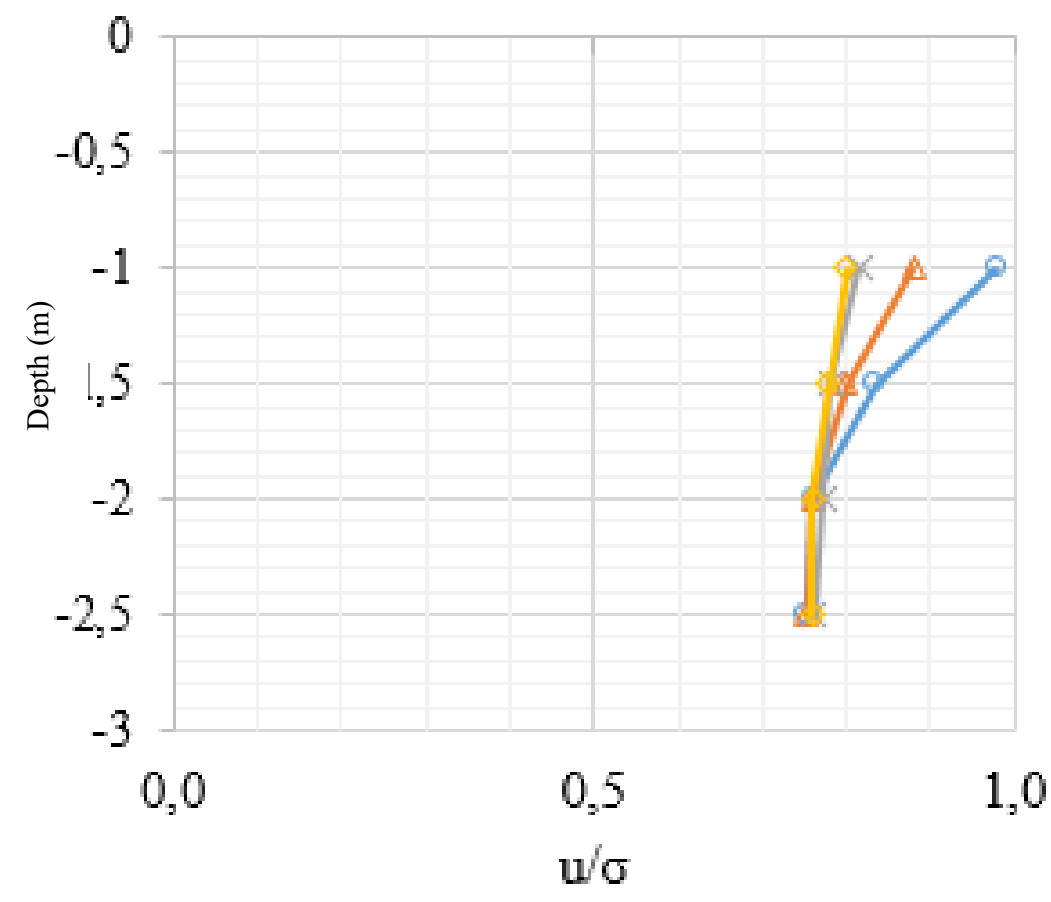

$\ldots$ Without stone column

$\leftarrow 2 \mathrm{~m}$ of stone column spacing

$\because 1.5 \mathrm{~m}$ of stone column spacing

$\rightarrow 1 \mathrm{~m}$ of stone column spacing

Figure 8. Curve of power water pressure ratio to total soil stress from $1 \mathrm{~m}$ to $2.5 \mathrm{~m}$ depth

Figure 8 is the potential condition for liquefaction during the 11 th-second earthquake. It can be seen that the addition of the stone column reduces the ratio between the pore water pressure and the total stress $(u / \sigma)$, indicating that the liquefaction potential is also decreasing. It can be concluded that the addition of a stone column with a variety of spacing of $2 \mathrm{~m}, 1.5 \mathrm{~m}$, and $1 \mathrm{~m}$ can reduce the liquefaction potential. The significant impact in reducing the liquefaction potential occur until $1.5 \mathrm{~m}$ depth.

\section{Conclusion}

Based on the results of the study, it can be concluded that the addition of the stone column to a loose sandy soil can reduce the liquefaction potential of the soil. The indicator of the decreasing liquefaction potential can be seen by the rate of increasing pore water pressure that reduced during an earthquake. The addition of the stone column can reduced the increasing of excess pore water pressure up to $40 \%$.

The variation in the spacing of stone column shows that the spacing of $1.5 \mathrm{~m}$ is the most effective option to achieve the maximum reduction of the increasing pore water pressure. It has an impact on decreasing the value of the ratio of pore pressure and total stress on the soil $(u / \sigma)$. The decreasing of $u / \sigma$ value represents the lower liquefaction potential, so it can be concluded that the addition of the stone column can reduce the potential of liquefaction in a liquefiable area.

\section{References}

[1] B. M. Das and G. V. Ramana, Principles of Soil Dynamics second edition. Stamford: Cengage Learning, 2011.

[2] T. W. Buana et al., "Atlas Zona Kerentanan Likuefaksi Indonesia,” Bandung, 2019.

[3] Committee on Earthquake Engineering, Liquefaction of Soil During Earthquakes. Washington D.C: National Academy Press, 1985.

[4] T. Shenthan, R. Nashed, S. Thevanayagam, and G. R. Martin, "Liquefaction mitigation in silty soils using composite stone columns and dynamic compaction," Earthquake Engineering and Engineering Vibration, vol. 3, no. 1, pp. 39-50, 2004, doi: 10.1007/BF02668849.

[5] Z. Ben Salem, W. Frikha, and M. Bouassida, "Effects of granular-column installation on excess pore pressure variation during soil liquefaction," International Journal of Geomechanics, vol. 16, no. 2, p. 04015046, Jun. 2015, doi: 10.1061/(ASCE)GM.1943-5622.0000516.

[6] J. Castro, Modelling Stone Columns. MDPI, 2017.

[7] M. Arif, A. Rifa'i, and F. Fikri, "Liquefaction potential analysis on runway construction based on soil engineering properties," 2020.

[8] A. Hara, T. Ohta, M. Niwa, S. Tanaka, and T. Banno, "Shear modulus and shear strenght of 
cohesive soil.," J-Stage, vol. 14, no. 3, pp. 1-12, Sep. 1974, doi: 10.3208/SANDF1972.14.3_1.

[9] R. Kumar, - Kapilesh Bhargava, and D. Choudhury, "Estimation of Engineering Properties of Soils from Field SPT Using Random Number Generation," INAE Letters 2016 1:3, vol. 1, no. 3, pp. 77-84, Oct. 2016, doi: 10.1007/S41403-0160012-6.
[10] Badan Standardisasi Nasional, SNI 8460:2017 Tata Cara Perencanaan Ketahanan Gempa untuk Struktur Bangunan Gedung dan Non Gedung. Jakarta: Badan Standardisasi Nasional, 2017.

[11] J. Castro, M. Karstunen, and N. Sivasithamparam, "Influence of stone column installation on settlement reduction," Computers and Geotechnics, vol. 59, pp. 87-97, Jun. 2014, doi: 10.1016/J.COMPGEO.2014.03.003. 